\title{
The effect of pentoxifylline on Achilles tendon healing in tenotomized rabbits
}

\author{
Tenotomize tavşanlarda pentoksifilinin Aşil tendonu iyileşmesi üzerine etkisi
}

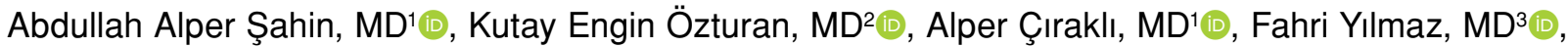

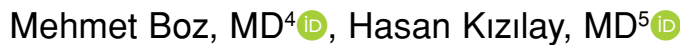

\begin{abstract}
${ }^{1}$ Department of Orthopedics and Traumatology, Ordu University Training and Research Hospital, Ordu, Turkey 2Department of Orthopedics and Traumatology, Abant İzzet Baysal University Faculty of Medicine, Bolu, Turkey

${ }^{3}$ Department of Pathology, Sakarya University Training and Research Hospital, Sakarya, Turkey

${ }^{4}$ Department of Orthopedics and Traumatology, Malatya Training and Research Hospital, Malatya, Turkey

${ }^{5}$ Department of Orthopedics and Traumatology, Gerede State Hospital, Bolu, Turkey
\end{abstract}

\begin{abstract}
Objectives: This study aims to evaluate the potential effects of pentoxifylline (PTX) on tendon healing and to compare the histopathological and biomechanical findings of the healed tendon among the groups.

Materials and methods: The study was conducted on 36 male New Zealand albino rabbits (age, 3 months; weighing, $2.5 \pm 0.5 \mathrm{~kg}$ ). Rabbits were randomized into two groups of 18 rabbits each. Partial Achilles tenotomy was performed $1.5 \mathrm{~cm}$ proximally from the calcaneal insertion of the tendon in both lower extremities of each rabbit and all groups were repaired primarily. After the operation, saline was injected intramuscularly to the control group and PTX was injected into the PTX group daily. Nine rabbits from each group were euthanized at weeks four and six postoperatively for histopathological $(n=4)$ and biomechanical $(n=5)$ testing. The histopathological findings were evaluated using the staging method of Curtis and Delee. Biomechanical effects were assessed by tensile testing.
\end{abstract}

Results: In the biomechanical evaluation results, the maximum displacement and maximum breaking force in the PTX group at fourth week were significantly higher than the control group. In the sixth week, the maximum breaking force in the control group was significantly higher than the PTX group. In the histopathological examination, collagen fiber alignment was more regular and vascularization was more frequent in the PTX group at both fourth and sixth weeks and the difference was significant.

Conclusion: Pentoxifylline increased healing and strength in rabbit Achilles tendon by stimulating collagen synthesis, increasing vascularity and reducing inflammation, particularly in the early period both histopathologically and biomechanically. According to our study, PTX may be favorable for the treatment of human Achilles tendon injuries and tendinopathies.

Keywords: Achilles tendon, pentoxifylline, rabbit, tendon healing.

\section{öz}

Amaç: $\mathrm{Bu}$ çalışmada pentoksifilinin (PTX) tendon iyileşmesindeki potansiyel etkileri değerlendirildi ve iyileşmiş tendonun histopatolojik ve biyomekanik bulguları gruplar arasında karşılaştırıldı.

Gereç ve yöntemler: Çalışma 36 erkek Yeni Zelanda albino tavşan üzerinde yapıldı (yaş, 3 ay; ağırlık, $2.5 \pm 0.5 \mathrm{~kg}$ ). Tavşanlar her grupta 18 tavşan olacak şekilde iki gruba randomize edildi. Her tavşanın her iki alt ekstremitesinde tendonun kalkaneal yerleşiminin $1.5 \mathrm{~cm}$ proksimalinden parsiyel Aşil tenotomisi uygulandı ve tüm gruplar primer olarak onarıldı. Ameliyattan sonra her gün kontrol grubuna intramusküler olarak serum fizyolojik, PTX grubuna ise PTX enjekte edildi. Her gruptan dokuz tavşana histopatolojik $(n=4)$ ve biyomekanik $(n=5)$ testler için ameliyattan dört ve altı hafta sonra ötenazi uyguland. Histopatolojik bulgular Curtis ve Delee'nin evreleme yöntemi kullanılarak değerlendirildi. Biyomekanik etkiler çekme testi ile değerlendirildi.

Bulgular: Biyomekanik değerlendirme sonuçlarında, dördüncü haftada PTX grubunda maksimum deplasman ve maksimum kopma kuvveti kontrol grubundan anlamlı derece yüksek idi. Altınc1 haftada, kontrol grubunda maksimum kopma kuvveti PTX grubundan anlamlı derecede yüksek idi. Histopatolojik incelemede, PTX grubunda hem dördüncü hem altıncı haftada kollajen lif dizilimi daha düzenli ve damarlanma daha fazla idi ve farklılık anlamlı idi.

Sonuç: Pentoksifilin kollajen sentezini uyararak, damarlanmayı artırıp enflamasyonu azaltarak özellikle erken dönemde hem histopatolojik hem biyomekanik olarak tavşan Aşil tendonunda iyileşme ve mukavemeti artırdı. Çalışmamıza göre, PTX insan Aşil tendonu yaralanmalarının ve tendinopatilerin tedavisi için uygun olabilir.

Anahtar sözcükler: Aşil tendonu, pentoksifilin, tavşan, tendon iyileşmesi.

Received: July 01, 2019 Accepted: July 17, 2019 Published online: October 24, 2019

Correspondence: Abdullah Alper Şahin, MD. Ordu Üniversitesi Eğitim ve Araştırma Hastanesi Ortopedi ve Travmatoloji Kliniği, 52200 Altınordu, Ordu, Turkey. Tel: +90 537 - 5960914 e-mail: dr.a.alpersahin@gmail.com 
Achilles tendon is the strongest and thickest tendon in the body. ${ }^{[1]}$ Rupture of this tendon generally occurs in males aged between 30 and 50 years during workouts, and its incidence is approximately $18 / 10,000$ individuals. ${ }^{[2,3]}$ Rupture of the Achilles tendon can be treated through conservative methods. ${ }^{[4]}$ One of the most controversial topics on tendon healing is undoubtedly related to Achilles tendon rupture..$^{[4]}$ In a recent study, it was detected that locally administered tranexamic acid has an adverse effect on tendon healing in late period..$^{[5]}$ Eren et al. ${ }^{[6]}$ reported that histopathological examination revealed that both low molecular weight heparin and rivaroxaban have positive effects on tendon healing. However, the same positive effects were not detected in biomechanical examination.

While plastering is used as a conservative method, open or percutaneous surgery can be used as surgical methods. In conservative methods, the rate of re-rupture is high and the duration of treatment is long. Conversely, surgical methods ensure early rehabilitation, with a relatively faster return to the pre-injury activity levels. . $^{[7-9]}$

Pentoxifyllin (PTX) is an inhibitor of xanthinederived phosphodiesterase and has a strong peripheral vasodilator effect. Its therapeutic effectiveness is based on its ability to increase blood flow and tissue oxygenation. ${ }^{[10]}$ Several studies have demonstrated that growth factors such as vascular endothelial growth factor (VEGF), transforming growth factor beta (TGF- $\beta$ ), platelet-derived growth factor, insulinlike growth factor-1, fibroblast growth factor and bone morphogenetic proteins (BMP-12 and BMP-13) are beneficial in tendon repair in animal models. ${ }^{[1-17]}$

Studies have shown that PTX suppresses inflammatory reactions by reducing the formation of mediators such as interleukin (IL)- 1 and IL-6. It has also been determined that PTX increases the levels of BMP-4, a member of the TGF- $\beta$ family. ${ }^{[18]}$ In this study, we aimed to evaluate the potential effects of PTX on tendon healing and to compare the histopathological and biomechanical findings of the healed tendon among the groups.

\section{MATERIALS AND METHODS}

The study protocol was approved by the Local Ethics Committee for Animal Experiments of Izzet Baysal University [09.11.2016 (No. 2016/44)]. The study was conducted between January 2017 and March 2017 in accordance with the principles of the Declaration of Helsinki. Three-month-old skeletally mature male New Zealand white rabbits $(\mathrm{n}=36,2.5 \pm 0.5 \mathrm{~kg}$, University of İzzet Baysal, Animal Laboratory, Bolu,
Turkey) were housed in cages and exposed to a diurnal light cycle. Animals were fed regularly with commercially available rabbit food. The temperature was kept between $22^{\circ}$ and $24^{\circ} \mathrm{C}$. The experiment was performed using 72 Achilles tendons from the 36 rabbits.

Thirty-six rabbits were randomly assigned to two groups with 18 rabbits per group. Partial Achilles tenotomy was performed $1.5 \mathrm{~cm}$ above the calcaneal insertion of the tendon in both lower extremities of each rabbit and all tendons were repaired primarily. After the operation, intramuscular (IM) saline was injected to the control group while PTX (100 mg/ $\mathrm{kg} /$ day) was injected into the PTX group daily. Nine rabbits from each group were euthanized at weeks four and six postoperatively for histopathological $(n=4)$ and biomechanical $(n=5)$ testing. The histopathological findings were evaluated using the staging method of Curtis and Delee. Biomechanical effects were assessed by tensile testing.

The operative procedure was performed under general anesthesia induced via IM injection of ketamine $35 \mathrm{mg} / \mathrm{kg}$ (ketamine hydrochloride, Ketalar $^{\circledR}$; EWL Eczacıbaşı Warner Lambert, Istanbul, Turkey) ten minutes after premedication with $5 \mathrm{mg} / \mathrm{kg}$ IM xylazine hydrochloride (Rompun, Bayer, Istanbul, Turkey). A single dose of Sefazol ${ }^{\circledR}$ (Cephazoline sodium, $20 \mathrm{mg} / \mathrm{kg}$, Mustafa Nevzat, İstanbul, Turkey) was applied to all animals preoperatively. The skin over both Achilles tendons was shaved and disinfected with povidone-iodine (Batticon ${ }^{\circledR}$, ADEKA, Samsun, Turkey). Thereafter, $1.5 \mathrm{~cm}$ incision was performed over the Achilles tendon. Following incision of the paratenon longitudinally, the tendon was tenotomized partially with a scalpel number 11, laterally from the midline of the tendon approximately $1.5 \mathrm{~cm}$ proximal to the calcaneal insertion. After tenotomy, all tendons were repaired primarily using $3 / 0$ polypropylene suture (Figure 1). Because of the partial tenotomy, the rabbits were not immobilized.

Following sacrification with high dose ether, eight tendons from each group were extracted by dissection at four and six weeks postoperatively for histopathological evaluation. Tendon pieces obtained from the healing region were fixed in $10 \%$ buffered neutral formalin, dehydrated using alcohol, and embedded in paraffin blocks. Sections of $5 \mu \mathrm{m}$ thickness were obtained and stained with hematoxylin and eosin and Mason's trichrome. The healing status of the tendons was evaluated on a binocular double-headed light microscope using Curtis and Delee's staging method. ${ }^{[19]}$ The degree of inflammation, neovascularization, fibroblastic 
activity, collagen fiber sequencing parameters were used in this staging method (Table I).

Biomechanical testing was achieved in the Technology Faculty Laboratories of the Kocaeli University. Ten tendons from each group were extracted by dissection at four and six weeks postoperatively for biomechanical evaluation. Before starting biomechanical measurements, the first length $(\mathrm{cm})$, thickness $(\mathrm{mm})$ and mass $(\mathrm{g})$ of the tendons were adjusted with electronic caliper and precision scales. Tension test was applied on tendons for biomechanical evaluation. Tensile tests were performed with equal distance between clamps $(3 \mathrm{~cm})$ and stretching speed of $10 \mathrm{~mm} / \mathrm{minute}$ for each tendon. The tests were terminated after the detection of a force decrease and rupture of the sample (Figure 2). Maximum tensile strength, maximum deformation and force values at the time of $2 \mathrm{~mm}$ gap in tendon were recorded by using tensile test at fourth and sixth weeks.

\section{Statistical analysis}

The chi-square test was used to detect any statistically significant differences in light microscopy findings. The F-test was used to determine whether the biomechanical data showed equal variance or not. Shapiro-Wilk test was used to determine whether the data were normally distributed or not. Unpaired Student-t test was used to compare the data showing normal distribution and equal variance. On the other hand, groups that were not normally distributed or had no equal variance were compared with the nonparametric Mann-Whitney test. Statistical analysis of the histopathological part of our study was performed using the IBM SPSS version 22.0 (IBM Corp., Armonk,
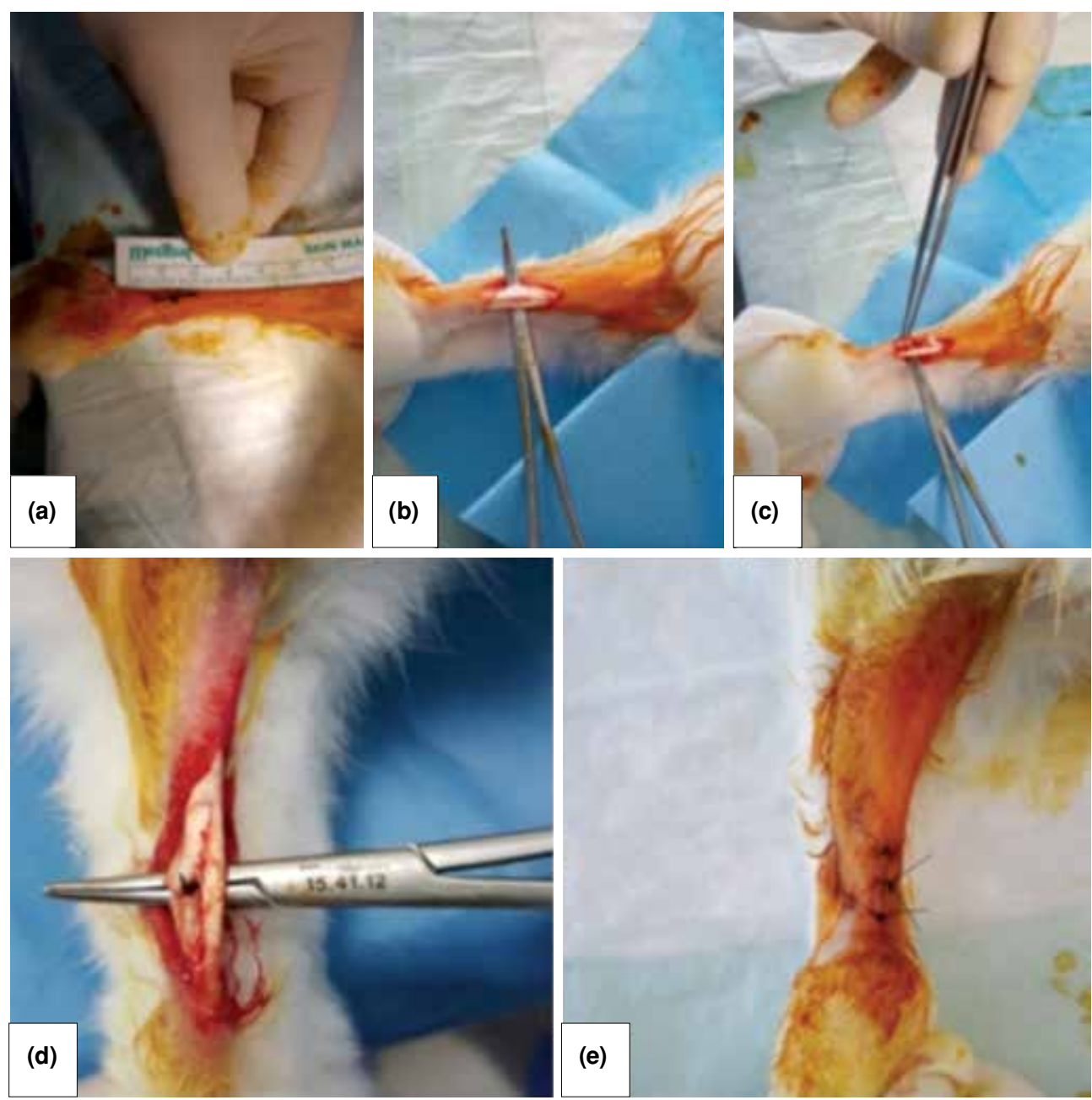

Figure 1. (a) Determination of incision line of tendon and skin. (b) Revealing Achilles tendon. (c) Calcaneus and gastrocnemius tips of Achilles tendon after partial tenotomy. (d) Primary repair of calcaneus and gastrocnemius tips of Achilles tendon after partial tenotomy. (e) Skin suturing and cleaning with Batticon ${ }^{\circledR}$ after repair. 


\section{TABLE}

Curtis and Delee's staging method

\begin{tabular}{ll}
\hline Tendon healing parameters & $\mathrm{n}$ \\
\hline Degree of inflammation & 0 \\
No inflammatory cells in the repair line at $\times 400$ magnification & 1 \\
Inflammatory cells in the repair line at $\times 400$ magnification & 0 \\
Neovascularization & 1 \\
No capillary vessel in a large magnification area & 2 \\
If the number of capillary vessels in a large magnification area is $0-5$ & 3 \\
If the number of capillary vessels in a large magnification area is 5-10 & \\
If the number of capillary vessels in a large magnification area is more than 10 & 0 \\
Fibroblastic activity (fibroplasia) & 1 \\
No fibroblast cells at the healing site of the repair line & 2 \\
Fibroblast cell minimal at the healing site of the repair line & \\
Fibroblast cell prominence in the healing region of the repair line & 0 \\
Collagen fiber sequencing & 1 \\
Sequencing of collagen fibers scattered & \\
Sequencing of collagen fibers regular &
\end{tabular}

NY, USA). Statistical analysis of the biomechanical part was performed with the help of the SigmaPlot 13.0 (Systat Software Inc., San Jose, CA, USA). The level of statistical significance was set as $\mathrm{p}<0.05$.

\section{RESULTS}

In the histopathological evaluation of the groups at weeks four and six, the ratio of vascularization and regular collagen fibers was found to be significantly higher in the PTX group $(\mathrm{p}<0.05)$ than in the control group (Figures 3,4 ). In terms of fibroblastic activity, no significant difference was identified between the two groups $(p>0.05)$. Similarly for inflammation, no significant difference was identified at week four ( $p>0.05$ ); however, the degree of inflammation at week six was significantly higher in the control group than in the PTX group $(\mathrm{p}<0.05)$ (Tables II and III).

In the biomechanical evaluation of the groups at week four, the maximum rupture force and maximum displacement were found to be significantly higher in the PTX group than in the control group $(\mathrm{p}<0.05)$. In terms of the $2 \mathrm{~mm}$-gap force, no significant difference was identified between the two groups $(\mathrm{p}>0.05)$. At week six, the maximum rupture force was significantly higher in the control group than in the PTX group $(\mathrm{p}<0.05)$. In terms of the maximum displacement and 2 mm-gap force, no significant difference was identified between the two groups ( $>>0.05)$ (Tables IV and V).
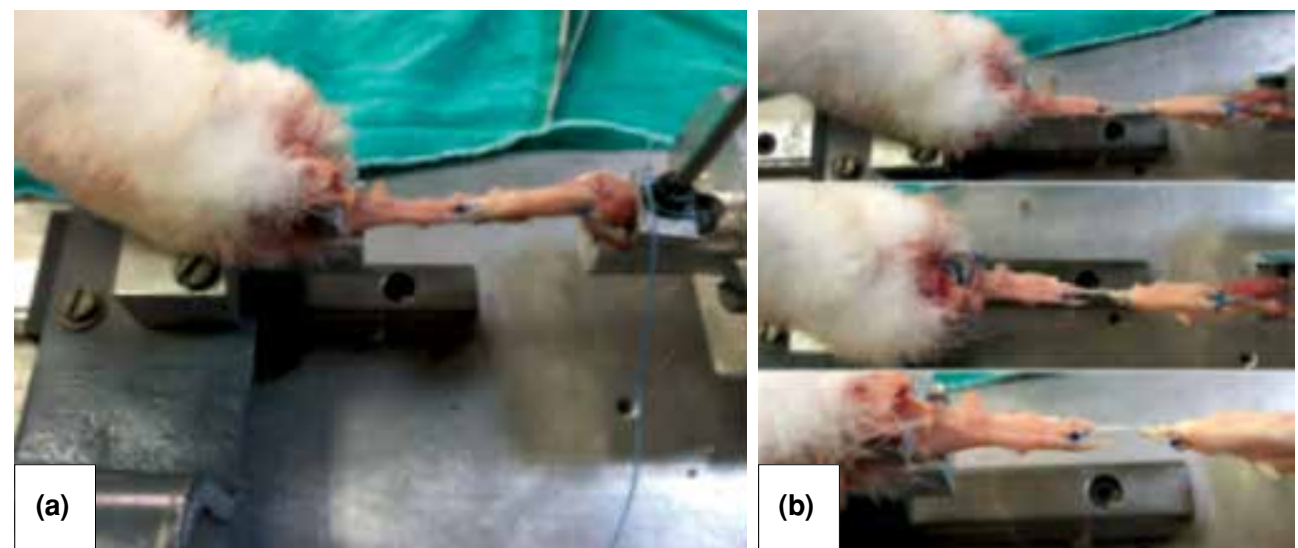

Figure 2. (a) Tendon sample placed between jaws. (b) Tensile appliance during tendon tensile test. 

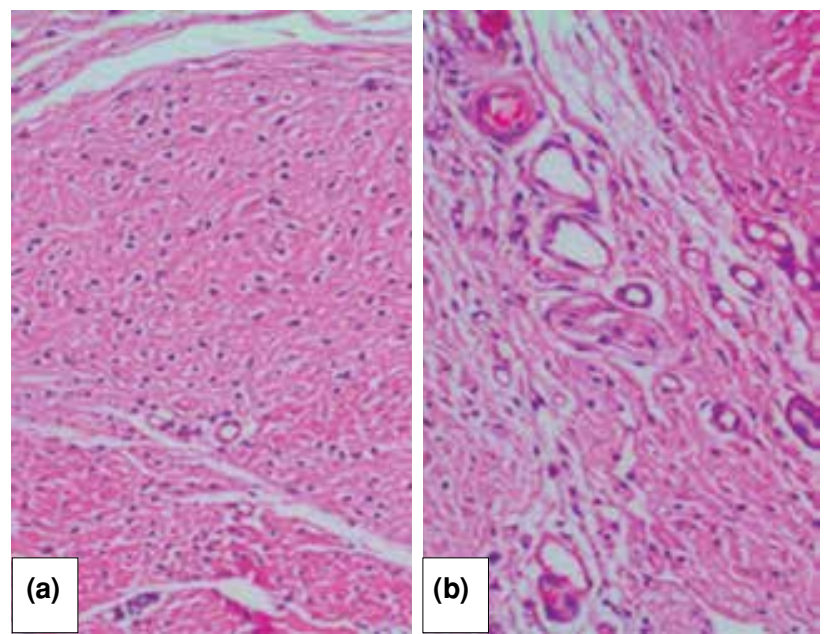

Figure 3. (a) Control group vascularization and fibroblastic activity $(\mathrm{H}-\mathrm{E} \times 100)$. (b) Pentoxifylline group vascularization $(H-E \times 200)$.

There was no infection or any other complication at the operation site and no death among the rabbits.

\section{DISCUSSION}

In our study, vascularization was found to be histopathologically higher in the PTX group than in the control group. The effects of PTX in stimulating neovascularization and microcirculation possibly resulted in an increase and acceleration of tendon repair.

The tendon healing process consists of cell proliferation, angiogenesis, extracellular matrix production and remodeling. The inflammatory phase, erythrocytes and inflammatory cells enter the site of injury and the necrotic tissue is phagocytosed by monocytes and macrophages. Subsequently, various extracellular matrix components begin to be synthesized by fibroblasts. Angiogenesis factors are released during this stage. ${ }^{[20]}$

There are many studies showing the positive effects of PTX on fracture, wound and nerve healing. Kurtoglu et al. ${ }^{[21]}$ investigated the effects of maternal nicotine exposure during pregnancy and lactation on neonatal rat bone formation and the protective effect of PTX. They concluded that PTX supplementation prevented the adverse effects of maternal nicotine exposure (such as decreased birth weight, pregnancy weight gain and bone lengthening) on bone mineral density and birth weight. Aydin et al. ${ }^{[22]}$ evaluated the effect of PTX on closed femur shaft fractures after two- and three-week periods. While they concluded that PTX accelerated healing histologically in the early phases of fracture healing, the authors reported that this effect decreases in the long term. Furthermore, infection rates in the PTX groups were high. Baykal et al. $^{[23]}$ reported that PTX has a positive effect on axon regeneration but no significant improving effect on segmental remyelination. Based on these studies about PTX, we investigated the effect of PTX on tendon healing.

In response to mechanical stress in tendons, IL-1 expression is regulated and contributes to the release of other cytokines involved in inflammation. This
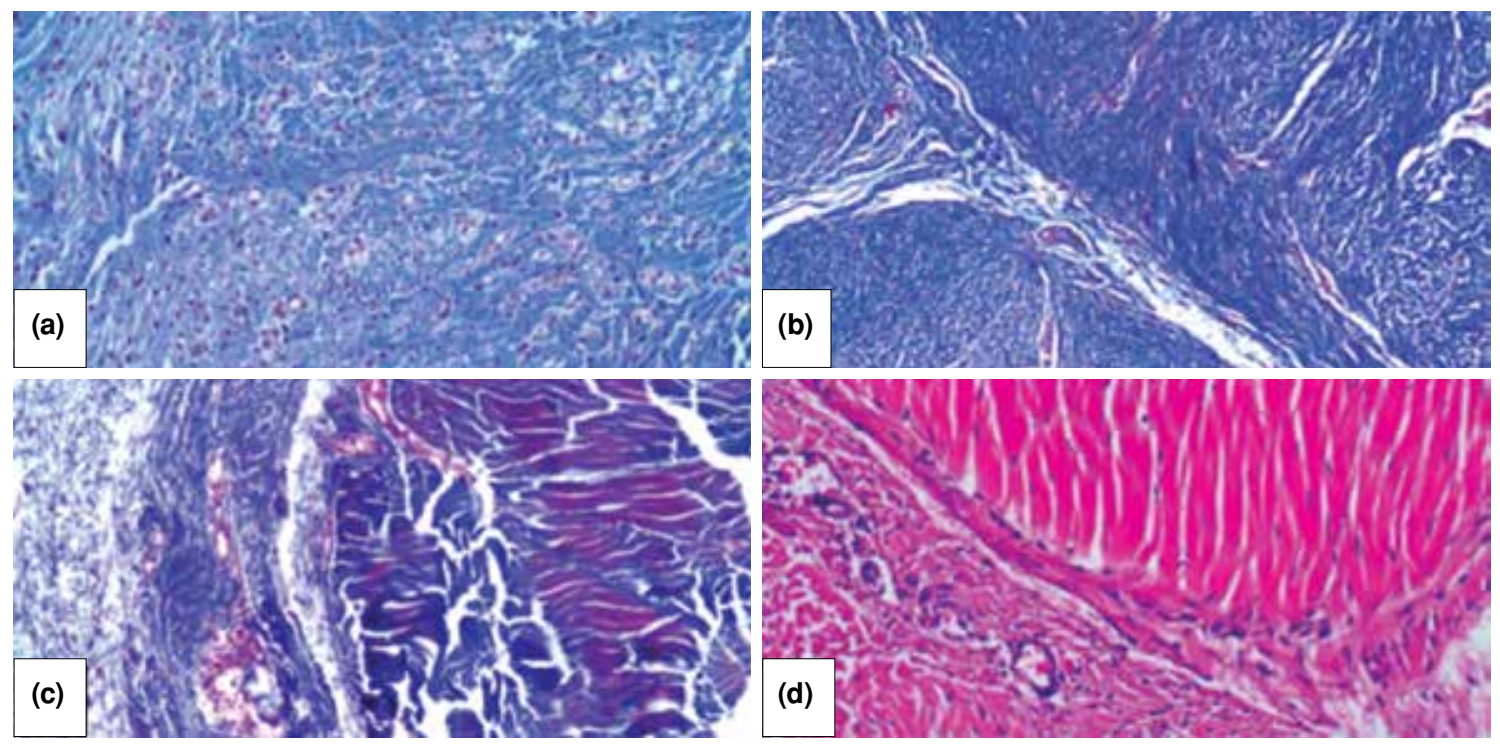

Figure 4. (a, b) Scattered, coarse collagen fiber sequencing of tendon in control group (H-E $\times 200)$. (c, d) Demonstration of regular collagen fiber sequencing of tendon in pentoxifylline group by Masson's trichrome and hematoxylin and eosin staining $(\mathrm{H}-\mathrm{E} \times 400)$. 
TABLE II

Fourth week histopathological parameter evaluation results

\begin{tabular}{|c|c|c|c|c|c|}
\hline & \multicolumn{2}{|c|}{ Control group $(n=8)$} & \multicolumn{2}{|c|}{ Pentoxifylline group $(n=8)$} & \multirow[b]{2}{*}{$p$} \\
\hline & $\mathrm{n}$ & $\%$ & $\mathrm{n}$ & $\%$ & \\
\hline Inflammatory cell & & & & & 0.13 \\
\hline Absent & 3 & 37.5 & 6 & 75 & \\
\hline Present & 5 & 62.5 & 2 & 25 & \\
\hline Neovascularization & & & & & 0.03 \\
\hline Absent & 0 & - & 0 & - & \\
\hline $0-5$ & 4 & 50 & 0 & - & \\
\hline $5-10$ & 3 & 37.5 & 3 & 37.5 & \\
\hline$>10$ & 1 & 12.5 & 5 & 62.5 & \\
\hline Fibroblastic activity & & & & & 0.14 \\
\hline Absent & 0 & - & 0 & - & \\
\hline Minimally & 2 & 25 & 4 & 50 & \\
\hline Pronounced & 6 & 75 & 4 & 50 & \\
\hline Collagen sequencing & & & & & 0.007 \\
\hline Scattered & 5 & 62.5 & 0 & - & \\
\hline Regular & 3 & 37.5 & 8 & 100 & \\
\hline
\end{tabular}

TABLE III

Sixth week histopathological parameter evaluation results

\begin{tabular}{|c|c|c|c|c|c|}
\hline & \multicolumn{2}{|c|}{ Control group $(n=8)$} & \multicolumn{2}{|c|}{ Pentoxifylline group $(n=8)$} & \multirow[b]{2}{*}{$p$} \\
\hline & $\mathrm{n}$ & $\%$ & $\mathrm{n}$ & $\%$ & \\
\hline Inflammatory cell & & & & & 0.04 \\
\hline Absent & 2 & 25 & 7 & 87.5 & \\
\hline Present & 6 & 75 & 1 & 12.5 & \\
\hline Neovascularization & & & & & 0.004 \\
\hline Absent & 0 & - & - & - & \\
\hline $0-5$ & 6 & 75 & - & - & \\
\hline $5-10$ & 2 & 25 & 3 & 37.5 & \\
\hline$>10$ & 0 & - & 5 & 62.5 & \\
\hline Fibroblastic activity & & & & & 0.20 \\
\hline Absent & 0 & - & - & & \\
\hline Minimally & 2 & 25 & 6 & 75 & \\
\hline Pronounced & 6 & 75 & 2 & 25 & \\
\hline Collagen sequencing & & & & & 0.01 \\
\hline Scattered & 4 & 50 & 0 & - & \\
\hline Regular & 4 & 50 & 8 & 100 & \\
\hline
\end{tabular}

pathway is a contributor to the inflammation present in tendinopathy and its inhibition may be of use in the treatment of tendinopathy. ${ }^{[2]}$ Berkoff et al. ${ }^{[18]}$ demonstrated that the use of IL-1 receptor antagonist positively affected the healing of tendinopathy in their study in rats. Pentoxifyllin reduces chemotactic mediators such as IL-1 and IL-6 and suppresses inflammatory reactions, particularly by reducing tumor necrosis factor-alpha. ${ }^{[25]}$ In the sixth week of our study, inflammation was significantly less in the PTX group on histopathological examination.

Bone morphogenetic proteins represent a group of proteins that are included in the TGF- $\beta$ family based on their structural characteristics. Reportedly, they play a role in the development and regeneration of bones and cartilage tissues. ${ }^{[26]}$ Jelinsky et al. ${ }^{[27]}$ have reported that recombinant human BMPs (rhBMP 12 and rhBMP 13) accelerate the Achilles tendon repair in a rat model. In a study conducted on PTX, it has been shown that PTX increases the levels of BMP-4. ${ }^{[25]}$ In our study, tendon repair in the PTX group was found to be better, both histopathologically and biomechanically, during the early period. Increased BMP-4 levels may be one of the factors contributing to this outcome. More accurate data can be obtained by quantitative measurement of BMP-4 level. 
TABLE IV

Fourth week control and pentoxifylline groups biomechanical data

\begin{tabular}{|c|c|c|c|}
\hline & Control group $(n=10)$ & Pentoxifylline group $(n=10)$ & \\
\hline & Mean \pm SD & Mean $\pm S D$ & $p$ \\
\hline $\begin{array}{r}\text { *2 mm gap forming force } \\
\text { (Mann-Whitney U test) }\end{array}$ & $16.671 \pm 14.891$ & $18.423 \pm 16.694$ & $>0.05$ \\
\hline $\begin{array}{l}\text { Maximum rupture Force } \\
\text { (unpaired student t-test) }\end{array}$ & $110.584 \pm 40.480$ & $153.043 \pm 57.150$ & $<0.05$ \\
\hline $\begin{array}{l}\text { Maximum displacement } \\
\text { (unpaired student t-test) }\end{array}$ & $12.289 \pm 3.413$ & $17.366 \pm 5.577$ & $<0.05$ \\
\hline
\end{tabular}

SD: Standard deviation; * Non-parametrik Mann Whitney-U test was used, was used because of data not showing normal distribution; Normality was evaluated with Shapiro-Wilk test.

TABLE V

Sixth week control and pentoxifylline groups biomechanical data

\begin{tabular}{|c|c|c|c|}
\hline & Control group $(n=10)$ & Pentoxifylline group $(n=10)$ & \\
\hline & Mean $\pm S D$ & Mean $\pm S D$ & $p$ \\
\hline $\begin{array}{l}2 \text { mm gap forming force } \\
\text { (unpaired student t-test) }\end{array}$ & $39.501 \pm 17.250$ & $28.433 \pm 15.638$ & $>0.05$ \\
\hline $\begin{array}{l}\text { Maximum rupture Force } \\
\text { (unpaired student t-test) }\end{array}$ & $135.279 \pm 68.392$ & $91.202 \pm 32.000$ & $<0.05$ \\
\hline $\begin{array}{l}\text { Maximum displacement } \\
\text { (unpaired student t-test) }\end{array}$ & $11.450 \pm 5.455$ & $9.612 \pm 3.208$ & $>0.05$ \\
\hline
\end{tabular}

SD: Standard deviation; Normality was evaluated with Shapiro-Wilk test. All data sets showed normal distribution (Shapiro-Wilk p>0.05).

During the inflammation stage of tendon recovery, angiogenic factors are released, the formation of vascular networks is initiated and stability of the injury site is ensured. Owing to this vascularization, chemotactic and growth factors migrate to the injury site and exhibit their effects. For this reason, we believe that an increase in vascularization results in a relatively faster tendon repair. In the study conducted by Çakmak et al. ${ }^{[28]}$ on the segmental bone defects in rats, it has been shown that PTX increases vascularization and angiogenesis in the defect area by increasing cluster of differentiation-31 (CD-31) and VEGF.

The study had an experimental design; hence we were unable to make comparisons in terms of clinical and functional outcomes. In our study, specific immunohistochemical staining can be performed to determine the type of collagen formed in the repair structure of Achilles tendons. In addition, we believe that a new study to increase the number of subjects can yield more meaningful results.

In conclusion, according to the histopathological data from the PTX group, it was observed that the homogeneity of collagen fibers was re-ensured and that the collagen was organized more regularly in this group. In our study, the ratio of new collagen that was synthesized at the recovery site was found to be significantly higher in the PTX group. Furthermore, the comparison on the basis of biomechanical data revealed that the maximum average weight that tendons can tolerate before rupturing is significantly higher in the PTX group. Thus, PTX may have a positive effect on tendon repair in rabbits. Use of PTX provides a relatively lower risk of re-rupture. Moreover, rehabilitation in the early stage can be initiated more safely when using PTX.

\section{Acknowledgement}

We would like to thank Assistant Professor Abdülkadir Cengiz, faculty member of Kocaeli University, Faculty of Technology, who assisted in biomechanical strength measurements.

\section{Declaration of conflicting interests}

The authors declared no conflicts of interest with respect to the authorship and/or publication of this article.

\section{Funding}

The authors received no financial support for the research and/or authorship of this article. 


\section{REFERENCES}

1. Maquirriain J. Achilles tendon rupture: avoiding tendon lengthening during surgical repair and rehabilitation. Yale J Biol Med 2011;84:289-300.

2. Genç E, Beytemur O, Yuksel S, Eren Y, Çağlar A, Küçükyıldırım BO, et al. Investigation of the biomechanical and histopathological effects of autologous conditioned serum on healing of Achilles tendon. Acta Orthop Traumatol Turc 2018;52:226-31.

3. Daghino W, Enrietti E, Sprio AE, di Prun NB, Berta GN, Massè A. Subcutaneous Achilles tendon rupture: A comparison between open technique and mini-invasive tenorrhaphy with Achillon ${ }^{\circledR}$ suture system. Injury 2016;47:2591-5.

4. Sezgin EA, Atik OŞ. Are orthobiologics the next chapter in clinical orthopedics? A literature review. Eklem Hastalik Cerrahisi 2018;29:110-6.

5. Çıraklı A, Gürgör PN, Uzun E, Erdem H, Çankaya S, Baş O. Local application of tranexamic acid affects tendon healing negatively in the late period. Eklem Hastalik Cerrahisi 2018;29:20-6.

6. Eren Y, Adanır O, Dinçel YM, Genç E, Arslan YZ, Çağlar A. Effects of low molecular weight heparin and rivaroxaban on rat Achilles tendon healing. Eklem Hastalik Cerrahisi 2018;29:13-9.

7. Olsson N, Silbernagel KG, Eriksson BI, Sansone M, Brorsson A, Nilsson-Helander $K$, et al. Stable surgical repair with accelerated rehabilitation versus nonsurgical treatment for acute Achilles tendon ruptures: a randomized controlled study. Am J Sports Med 2013;41:2867-76.

8. Doral MN, Bozkurt M, Turhan E, Ayvaz M, Atay OA, Uzümcügil A, et al. Percutaneous suturing of the ruptured Achilles tendon with endoscopic control. Arch Orthop Trauma Surg 2009;129:1093-101.

9. Nilsson-Helander K, Silbernagel KG, Thomeé R, Faxén E, Olsson N, Eriksson BI, et al. Acute achilles tendon rupture: a randomized, controlled study comparing surgical and nonsurgical treatments using validated outcome measures. Am J Sports Med 2010;38:2186-93.

10. Ward A, Clissold SP. Pentoxifylline. A review of its pharmacodynamic and pharmacokinetic properties, and its therapeutic efficacy. Drugs 1987;34:50-97.

11. Majewski M, Ochsner PE, Liu F, Flückiger R, Evans $\mathrm{CH}$. Accelerated healing of the rat Achilles tendon in response to autologous conditioned serum. Am J Sports Med 2009;37:2117-25.

12. Zhang F, Liu H, Stile F, Lei MP, Pang Y, Oswald TM, et al. Effect of vascular endothelial growth factor on rat Achilles tendon healing. Plast Reconstr Surg 2003;112:1613-9.

13. Wang XT, Liu PY, Tang JB. Tendon healing in vitro: genetic modification of tenocytes with exogenous PDGF gene and promotion of collagen gene expression. J Hand Surg Am 2004;29:884-90.

14. Drissi H, Lomri A, Lasmoles F, Holy X, Zerath E, Marie PJ. Skeletal unloading induces biphasic changes in insulin-like growth factor-I mRNA levels and osteoblast activity. Exp Cell Res 1999;251:275-84.

15. Thomopoulos S, Das R, Sakiyama-Elbert S, Silva MJ, Charlton N, Gelberman RH. bFGF and PDGF-BB for tendon repair: controlled release and biologic activity by tendon fibroblasts in vitro. Ann Biomed Eng 2010;38:225-34.

16. Forslund C, Rueger D, Aspenberg P. A comparative doseresponse study of cartilage-derived morphogenetic protein (CDMP)-1, -2 and -3 for tendon healing in rats. J Orthop Res 2003;21:617-21.

17. Longo UG, Lamberti A, Maffulli N, Denaro V. Tissue engineered biological augmentation for tendon healing: a systematic review. Br Med Bull 2011;98:31-59.

18. Berkoff DJ, Kallianos SA, Eskildsen SM, Weinhold PS. Use of an IL1-receptor antagonist to prevent the progression of tendinopathy in a rat model. J Orthop Res 2016;34:616-22.

19. Curtis RJ, Delee JC, Drez DJ Jr. Reconstruction of the anterior cruciate ligament with freeze dried fascia lata allografts in dogs. A preliminary report. Am J Sports Med 1985;13:408-14.

20. Sharma P, Maffulli N. Tendon injury and tendinopathy: healing and repair. J Bone Joint Surg [Am] 2005;87:187202.

21. Kurtoglu S, Gunes T, Koklu E, Bastug O, Canoz O, Kula M, et al. Influence of maternal nicotine exposure on neonatal rat bone: protective effect of pentoxifylline. Exp Biol Med (Maywood) 2007;232:398-405.

22. Aydin K, Sahin V, Gürsu S, Mercan AS, Demir B, Yildirim T. Effect of pentoxifylline on fracture healing: an experimental study. Eklem Hastalik Cerrahisi 2011;22:160-5.

23. Baykal S, Boz C, Çakır E, Baytan ŞH, Karakuş M, Kuzeyli K. The effects of pentoxifylline in experimental nerve injury. Turkish Journal of Medical Sciences 2002;32:207-10.

24. Uchida H, Tohyama H, Nagashima K, Ohba Y, Matsumoto $\mathrm{H}$, Toyama $\mathrm{Y}$, et al. Stress deprivation simultaneously induces over-expression of interleukin-1beta, tumor necrosis factor-alpha, and transforming growth factor-beta in fibroblasts and mechanical deterioration of the tissue in the patellar tendon. J Biomec 2005;38:791-8.

25. Tsutsumimoto T, Wakabayashi S, Kinoshita T, Horiuchi H, Takaoka K. A phosphodiesterase inhibitor, pentoxifylline, enhances the bone morphogenetic protein-4 (BMP-4)dependent differentiation of osteoprogenitor cells. Bone 2002;31:396-401.

26. Carreira AC, Alves GG, Zambuzzi WF, Sogayar MC, Granjeiro JM. Bone Morphogenetic Proteins: structure, biological function and therapeutic applications. Arch Biochem Biophys 2014;561:64-73.

27. Jelinsky SA, Li L, Ellis D, Archambault J, Li J, St Andre M, et al. Treatment with rhBMP12 or rhBMP13 increase the rate and the quality of rat Achilles tendon repair. J Orthop Res 2011;29:1604-12.

28. Çakmak G, Şahin MŞ, Özdemİr BH, Karadenİz E. Effect of pentoxifylline on healing of segmental bone defects and angiogenesis. Acta Orthop Traumatol Turc 2015;49:676-82. 